\title{
Ecologically relevant choanoflagellates collected from hypoxic water masses of the Baltic Sea have untypical mitochondrial cristae
}

\author{
Claudia Wylezich $^{1 *}$, Sergey A Karpov²*, Alexander P Mylnikov³ ${ }^{2}$ Ruth Anderson ${ }^{1}$ and Klaus Jürgens ${ }^{1}$
}

\begin{abstract}
Background: Protist communities inhabiting oxygen depleted waters have so far been characterized through both microscopical observations and sequence based techniques. However, the lack of cultures for abundant taxa severely hampers our knowledge on the morphology, ecology and energy metabolism of hypoxic protists. Cultivation of such protists has been unsuccessful in most cases, and has never yet succeeded for choanoflagellates, even though these small bacterivorous flagellates are known to be ecologically relevant components of aquatic protist communities.

Results: Quantitative data for choanoflagellates and the vertical distribution of Codosiga spp. at Gotland and Landsort Deep (Baltic Sea) indicate its preference for oxygen-depleted zones. Strains isolated and cultivated from these habitats revealed ultrastructural peculiarities such as mitochondria showing tubular cristae never seen before for choanoflagellates, and the first observation of intracellular prokaryotes in choanoflagellates. Analysis of their partial $28 \mathrm{~S}$ rRNA gene sequence complements the description of two new species, Codosiga minima n. sp. and C. balthica n. sp. These are closely related with but well separated from C. gracilis (C. balthica and C. minima p-distance to C. gracilis 4.8\% and $11.6 \%$, respectively). In phylogenetic analyses the $18 \mathrm{~S}$ rRNA gene sequences branch off together with environmental sequences from hypoxic habitats resulting in a wide cluster of hypoxic Codosiga relatives so far only known from environmental sequencing approaches.

Conclusions: Here, we establish the morphological and ultrastructural identity of an environmental choanoflagellate lineage. Data from microscopical observations, supplemented by findings from previous culture-independent methods, indicate that C. balthica is likely an ecologically relevant player of Baltic Sea hypoxic waters. The possession of derived mitochondria could be an adaptation to life in hypoxic environments periodically influenced by small-scale mixing events and changing oxygen content allowing the reduction of oxygen consuming components. In view of the intricacy of isolating and cultivating choanoflagellates, the two new cultured species represent an important advance to the understanding of the ecology of this group, and mechanisms of adaptations to hypoxia in protists in general.
\end{abstract}

\section{Background}

Choanoflagellates are colourless, free-living, exclusively heterotrophic protists that are characterized by a single anterior flagellum surrounded by a collar of microvilli; and flat cristae in the mitochondria [1]. These unikont flagellates form the sister taxon of metazoans as seen by

\footnotetext{
* Correspondence: claudia.wylezich@io-warnemuende.de;

sakarpov4@gmail.com

${ }^{1}$ IOW-Leibniz Institute for Baltic Sea Research Warnemünde, Rostock, Germany

${ }^{2}$ Zoological Institute RAS and St. Petersburg State University, St. Petersburg, Russia

Full list of author information is available at the end of the article
}

sequence analyses [2-4]. Within the choanoflagellates, three families were originally distinguished based on morphology: Acanthoecidae Norris, 1965; Salpingoecidae Kent, 1880; and Codonosigidae Kent, 1880 (synonym Monosigidae Zhukov et Karpov, 1985). Recent taxonomic revision based on multigene analysis states that the class Choanoflagellatea Kent, 1880 comprises two orders: 1) Craspedida, with a single family Salpingoecidae (including the aloricate choanoflagellates of the former Codonosigidae and Salpingoecidae families); and 2) Acanthoecida, with the families Acanthoecidae and Stephanoecidae [5,6]. Choanoflagellates normally constitute 5 to $40 \%$ of the average heterotrophic nanoflagellates (HNF) biomass in

\section{Biomed Central}


oxygenated pelagic habitats $[7,8]$. They have also been detected in hypoxic (oxygen-deficient) water masses [9] and can constitute a significant proportion of total HNF biomass, reaching for example 10-40\% in hypoxic water masses of the Baltic Sea [10]. Especially in Gotland Deep, the biomass of exclusively aloricate choanoflagellates can clearly exceed 40\% [10]. However, to date, few choanoflagellate species have been successfully cultured [5], and none for hypoxic environments, limiting knowledge on the ecology of this ecologically relevant protist group.

Clone library based approaches have produced many novel sequence types during the last decade, enhancing our knowledge of protist species richness and diversity $[11,12]$. However, morphological and quantitative data of microscopical life observations and cell counts are often hard to match with such environmental sequences. In some recent cases it has been possible to assign new described species to novel protistan lineages only known from culture-independent sequence investigations [13-15]. Many environmental sequences (18S rRNA) in public databases cluster within the choanoflagellates. A recent re-analysis of published environmental sequences belonging to this group $[16,17]$ provided evidence for only a low correspondence between these sequences and sequences obtained from cultures. Clonal sequences from hypoxic environments (here referring to suboxic to anoxic/sulfidic conditions) have also been found to often cluster within the choanoflagellates. For instance, sequences from the anoxic Framvaren Fjord [18] branch off near Diaphanoeca grandis (Stephanoecidae); and clonal sequences found in the hypersaline Mediterranean L'Atalante Basin constitute the novel cluster $F$ within the Acanthoecidae $[16,19]$. Stock et al. [20] also detected novel sequences in the redoxcline of the periodically anoxic Gotland Deep (central Baltic Sea), which branched within the Craspedida cluster A [16]. However, only a small fraction of choanoflagellates known at a sequence level have been isolated and maintained in culture to date, and none so far was derived from hypoxic marine environments. Thus, the morphology, ultrastructure and physiological strategies of these choanoflagellates from hypoxic environments remain unexplored.

The Baltic Sea is one of the largest brackish water basins in the world. A stable halocline separates the water column into an upper oxygenated layer and underlying oxygen deficient and anoxic/sulfidic layers in the deeper basins (e.g., Gotland and Landsort Deep). Protist communities inhabiting these oxygen depleted layers have been characterized so far by microscopical counting of stained specimens [21-23] and clone library investigations [20]. However, in contrast to well characterized prokaryotic communities inhabiting these zones [24-26], little is known on the ecology and ultrastructure of individual protist groups living there.
The aim of this survey was to successfully isolate and cultivate ecologically relevant protist strains from hypoxic water masses of the Baltic Sea and characterize the morphological and ultrastructural traits that could allow them to succeed in these environments. In the present study we present two successfully cultured choanoflagellate isolates of the genus Codosiga, which present mitochondria with tubular cristae and endobiotic bacteria, never seen before for choanoflagellates, which could represent an adaptation to life in an environment with fluctuating oxygen content.

\section{Results}

\section{Vertical distribution and abundance of choanoflagellates}

In 2005, an analysis of Codosiga spp. and its vertical distribution was conducted through light and electron microscopy (Figure 1A) for the whole water column of Landsort and Gotland Deep (Figure 1B, C). The detected Codosiga specimens showed a preference for suboxic and anoxic water layers in both sites. In Gotland Deep the cells were mainly detected in sulfidic waters below the chemocline (defined by the first appearance of hydrogen sulfide). The HNF cell counts from the redoxclines in 2008 and 2009 (Figure 2) are shown as the abundance of total heterotrophic flagellates and the relative proportion of aloricate choanoflagellates (including Codosiga and other naked genera). Choanoflagellates were numerically important components in Gotland Deep, but represented only a small fraction of total HNF in Landsort Deep (Figure 2). Their abundance was highest at suboxic and interface depths ranging from 20 to $30 \%$ of total HNF counts in Gotland Deep and about 5\% Landsort Deep.

\section{Phylogenetic reconstructions using ribosomal gene sequences}

Nearly complete $18 \mathrm{~S}$ rRNA gene sequences were obtained for both strain IOW73 (1748 base pairs in length), and strain IOW94 (1783 base pairs). Additionally, we generated partial 28S rRNA sequences for both strains to enable comparison with Codosiga gracilis from GenBank (the 18S rRNA sequence is missing for this unique Codosiga culture, see [6]). The $28 \mathrm{~S}$ sequences obtained, including the divergent D1-D6 regions, possessed a length of 1620 and 1612 base pairs for strain IOW73 and strain IOW94, respectively.

Strains IOW73 and IOW94 belong to the Salpingoecidae according to [6] and branched off with clade 1 by Carr et al. [5], and clade A by del Campo \& Massana [16]. The 18S rRNA tree (Figure 3) additionally contains environmental sequences from different habitats closely related to clade A. The Codosiga sequences form a well supported clade with sequences from hypoxic habitats such as the Baltic Sea (Gotland Deep), Framvaren Fjord, 


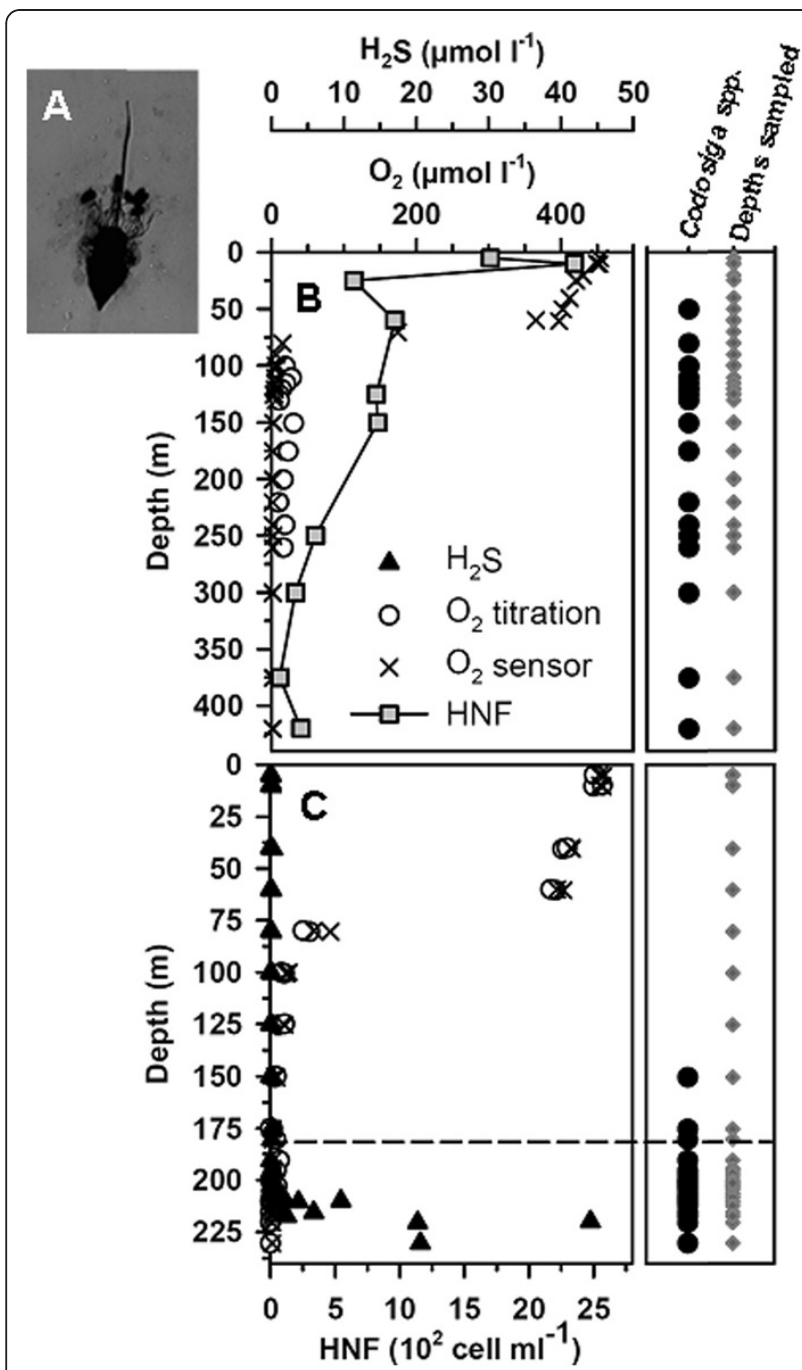

Figure 1 Vertical distribution of Codosiga spp. indentified in May 2005, and assessment of their presence (black circles) / absence (no symbol) at different depths (grey diamonds) throughout the whole water column of Landsort Deep (B) and Gotland Deep (C). Oxygen concentrations (measured by titration and by the oxygen sensor on the (TD) and hydrogen sulfide concentrations (only available for Gotland Deep) are also shown, along with cell-counts for Landsort Deep. Data were pooled for several different CTD casts. The dashed line represents the chemocline. Codosiga spp. was identified by life observations and scanning electron microscopy as shown (A).

the Black Sea and Sagami Bay, Japan. The only exceptional sequence in this clade, that was not isolated from hypoxic environment, is AJ402325 from the Pacific [27] which forms the basal branch. We were able to establish cultures for two further strains, IOW74 (Gotland Deep, $208 \mathrm{~m}$ ) and IOW75 (Landsort Deep, $260 \mathrm{~m}$ ), whose short 18S rRNA sequence fragments are identical to strain IOW73 (data not shown).

The phylogenetic tree based on partial 28S rRNA gene sequences, excluding the highly divergent D2 region, shows a well established branching order in the Craspedida and Acanthoecida (Figure 4). Sequences of our new isolates are closely related to Codosiga gracilis ATCC50454, rendering the genus Codosiga monophyletic. Strain IOW94 is more closely related to $C$. gracilis ( $p$-distance $4.8 \%$ ) than IOW73 ( $p$-distance to C. gracilis 11.6\%).

\section{Cultivation and morphology}

Choanoflagellate cultures were maintained under oxic conditions. The culture development in both strains was similar during the first 4-6 days after inoculation to fresh medium, though strain IOW94 proliferated one to two days slower under the same conditions, and tends to aggregate to clumps of bacteria. On days 2 to 3 , strains demonstrated solitary cells on a stalk of different lengths (Figures 5, 6). On days 3 to 4, the development of two-cell colonies appeared (Figure 6A). Such colony types were common for IOW73, and are also typical for Codosiga gracilis de Saedeleer, 1927 (basionym Monosiga gracilis Kent, 1880), but with larger cell dimensions. Strain IOW94 normally produced 2-4 cell colonies, though occasionally largely colonies were formed.

Strain IOW94 was present as sedentary stalked solitary cells and as colonies. It has a flask-shaped cell with a broad and short neck covered with a very delicate, tightly enveloping, theca (see ultrastructure below). The inconspicuous profile of the theca opening is visible in some cells as "whiskers" at the base of the collar (Figure 5A, arrowheads). Length of the body is $3-4.5 \mu \mathrm{m}$, width $2 \mu \mathrm{m}(\mathrm{n}=18)$. The length of the collar is equal to the body length, the flagellum is approx. 2 times longer than the body and the stalk covers up to 3 body lengths.

Strain IOW73 was present as sedentary stalked solitary cells and as colonies of $2-4$ cells (Figure 6A). The most typical colonies were two cells on a rather long stalk (up to $7 \mu \mathrm{m}$ ). The strain has an elongated vase-shaped cell with a narrow and prominent neck, surrounded with a delicate, tightly enveloping, theca (see ultrastructure) with visible whisker. The body length is $2-4 \mu \mathrm{m}$, width $-1 \mu \mathrm{m}$ $(n=22)$. The length of the collar is equal to the body; the flagellum is 1.5-2 times longer than the body.

The cell shape of both strains is similar to C. gracilis, studied by Leadbeater and Morton [28]. A contractile vacuole was not visible for cells cultivated at $22 \%$ but appeared when the salinity was reduced to $8-10 \%$ (Figure 6A, B).

\section{Ultrastructure}

The electron microscopical investigations revealed an in general typical choanoflagellate cell structure for both strains (Figures 5, 6). As in many others colonial choanoflagellates: (1) the cells were covered with a thin sheath, which envelopes the whole body and the base of the collar (Figures 5A, B, 6B); (2) the collar was composed of approximately 30 microvilli in both isolates (not shown); (3) 


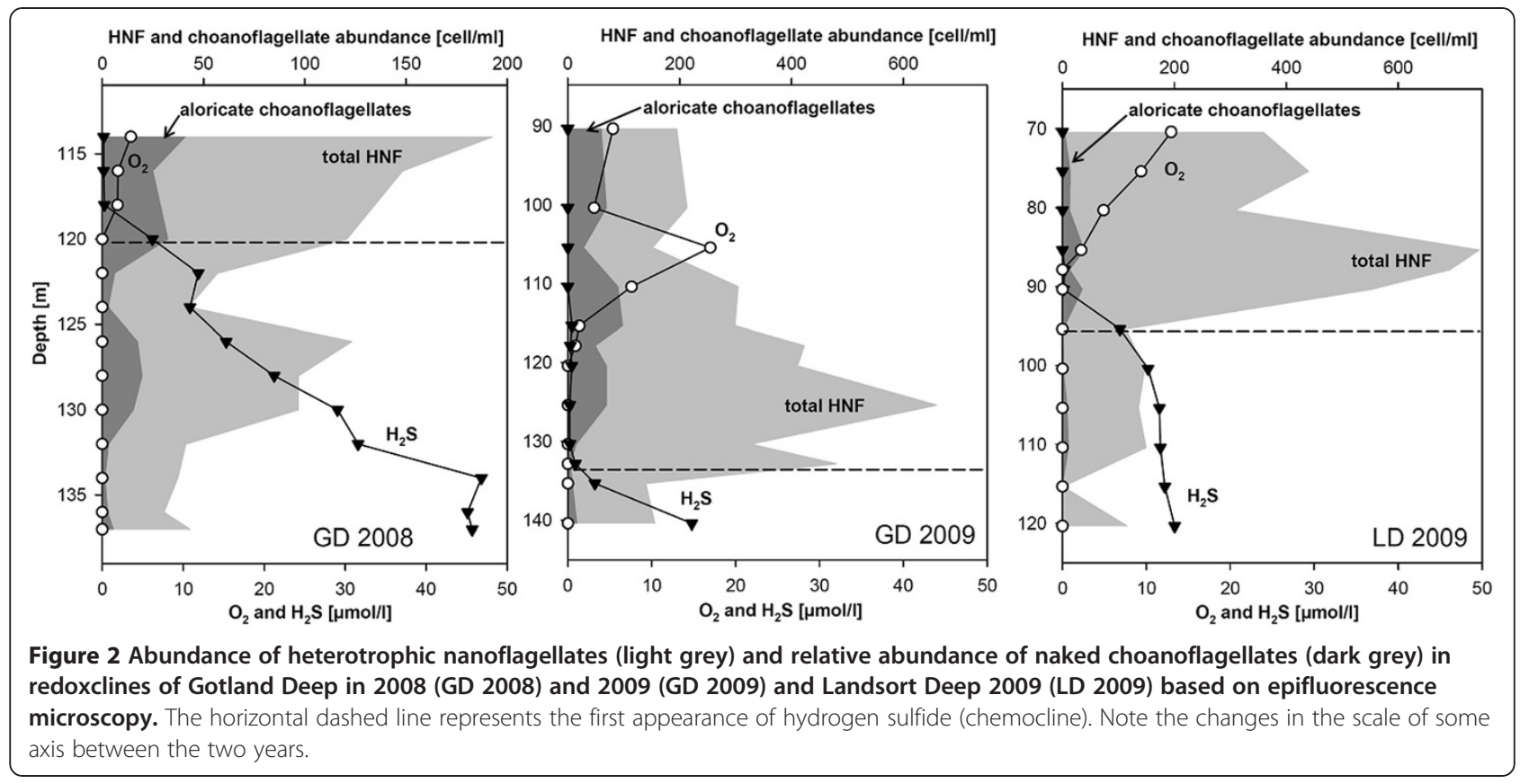

the Golgi apparatus lies under the base of flagellum (Figure 5B); (4) the flagellar apparatus has a long transition zone, a flagellar kinetosome with radiating microtubules, and a non-flagellar centriole, all typical for choanoflagellates (Figure 5B, 6D); (5) a nucleus of vesicular type (Figure $6 \mathrm{~B}$ ) is located in the anterior-middle part of the cell; and (6) other organelles and inclusions are also those common for choanoflagellates. Additionally, food vacuoles with bacteria in different stages of digestion were found in the posterior half of the cell, and a contractile vacuole is located at the cell posterior. This latter structure has the typical appearance of a folded reservoir with coated pits and vesicles around it (Figure 6B). Finally, lipid droplets occur in the cytoplasm of some cells (Figures 5D, G, 6C).

In contrast to these similarities, the internal structure of mitochondria-the shape of the cristae-is cardinally different from all other choanoflagellates investigated to date. The cells in both strains have mitochondria with tubular or sac-like cristae (Figure 1B including left upper insert, 5F, G, 6B insert lower left). In both types the cristae have tubular or saccular shape (Figure 5B, F, G). In the strain IOW94 mitochondria of two types can be seen: with normal matrix and developed cristae (Figure 5B, F), and with light matrix and rare cristae (Figure 5G).

Another peculiarity is the presence of many intracellular, potentially symbiotic bacteria in the cytoplasm of strain IOW94, predominantly in the cell posterior (Figure 5C). These prokaryotes are not limited with membranes, instead lying freely in the cytosol, and seem to belong to Gram-negative bacteria (Figure 5C, D, G) due to the two covering membranes (Figure 5D). They are represented by at least two types: long narrow (nlb) and big flagellated bacteria (bfb). The bfb have a set of rather long flagella which are tubular in cross section (Figure 5D) and tend to associate with lipid globules (Figure 5D, E, G).

\section{Mode of feeding}

Live observations of both strains revealed a typical Monosiga-type mode of feeding [29,30]. The feeding pseudopodium arises from the top of the neck outside the collar, grows towards the bacterium on the outer surface of the collar and engulfs the prey producing a food vacuole. These observations were confirmed by cross sections through the collar base (Figure 6B, insert). Additionally, feeding pseudopodia arising from the side of the neck were found for both strains (Figure 6C). This mode of engulfment is typical for Codosiga and some other colonial choanoflagellates with a thin sheath around the cell $[29,30]$. The presence of two feeding modes is easily explained by the combination of solitary and colonial life styles for both strains: solitary cells feed in Monosiga-type mode, and colonial cells feed as other colonial choanoflagellates (Codosiga, Desmarella, Sphaeroeca).

\section{Formal taxonomic description}

Codosiga balthica sp. nov. Wylezich et Karpov (Choanoflagellatea (Kent) Cavalier-Smith, 1998, Craspedida Cavalier-Smith, 1997; Salpingoecidae (Kent) Nitsche et al., 2011).

Diagnosis: Sedentary stalked solitary cells with rare production of colonies of 2-4 cells. Flask-shaped cell with a broad and short neck surrounded by a delicate 


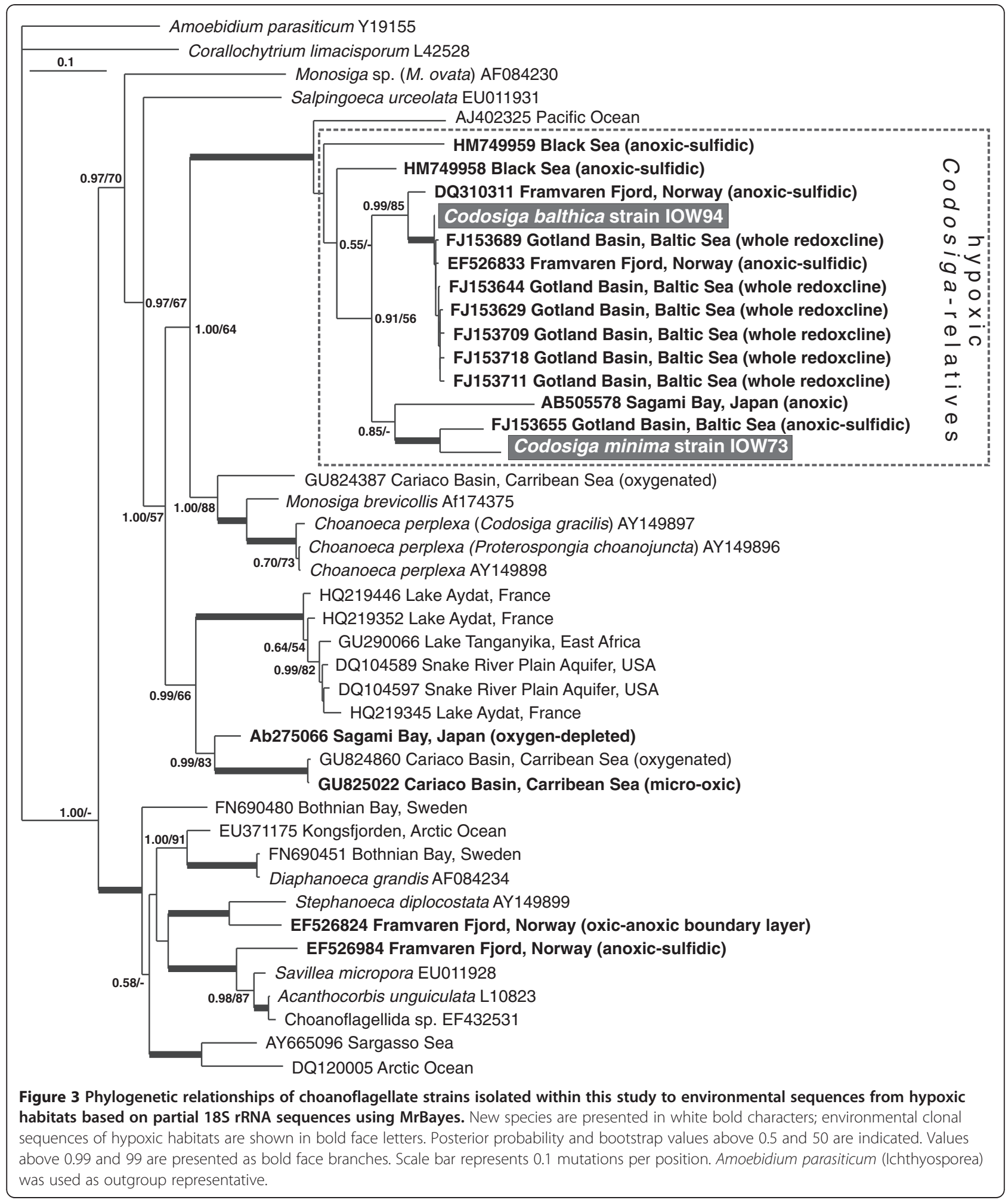

sheath, visible through electron microscopy. Dimensions: body length - 3-4.5 $\mu \mathrm{m}$, width $-2 \mu \mathrm{m}$, length of the collar equal to the body, flagellum 2-2.5 times longer than the body, stalk: up to 3 body lengths. Tubular or saccular mitochondrial cristae, intracellular flagellated bacteria present in cytosol not limited with membrane. Observed habitat: Gotland Deep (central Baltic Sea, IOW station $271,57^{\circ} 19^{\prime} \mathrm{N}, 20^{\circ} 10^{\prime} \mathrm{E}$ ) suboxic to anoxic water masses (depth $206 \mathrm{~m}$ ), brackish (8-25\%); Type material: iconotypes: Figure 5D, E; fixed and embedded specimens 


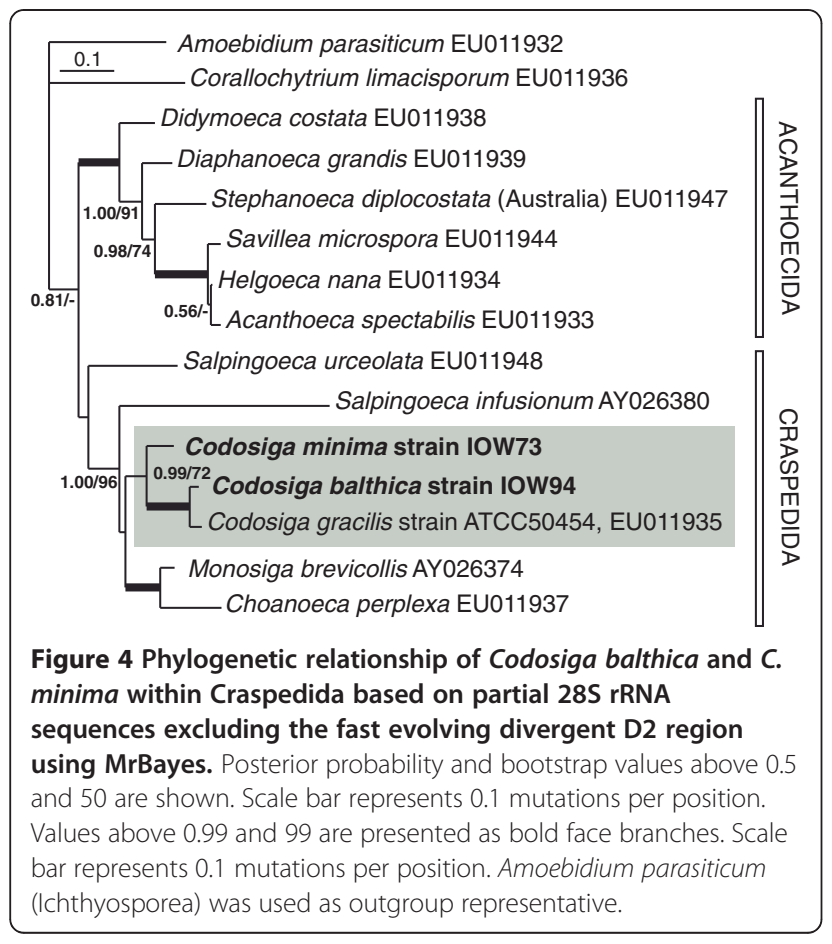

(hapantotypes) are deposited at the Oberösterreichische Landesmuseum in Linz, Austria (inventory number 2012/121); live strains (paratypes) are held as clonal cultures (strain IOW94) in the laboratory of the Leibniz Institut for Baltic Sea Research in RostockWarnemünde; Etymology: balthica after the Baltic Sea, where the strain was isolated. Closely related clonal sequences were available from Gotland Deep and Framvaren fjord but not from other habitats, oxic or hypoxic.

Codosiga minima sp. nov. Wylezich et Karpov (Choanoflagellatea (Kent) Cavalier-Smith, 1998, Craspedida Cavalier-Smith, 1997; Salpingoecidae (Kent) Nitsche et al., 2011).

Diagnosis: Sedentary stalked solitary cells which rarely produce colonies of 2-4 cells. Elongated vase-shaped cell with a prominent neck, surrounded by a delicate sheath visible through electron microscopy. Dimensions: body length $-2-3 \mu \mathrm{m}$, width $-1 \mu \mathrm{m}$, length of the collar equal to the body, flagellum 1,5-2 times longer than the body, stalk is up to $7 \mu \mathrm{m}$. Profiles of the mitochondrial cristae of oval shape. Observed habitat: Gotland Deep and Landsort Deep (central Baltic Sea, IOW station 284, 58 $35^{\prime} \mathrm{N}, 18^{\circ} 14^{\prime} \mathrm{E}$ ) suboxic to anoxic water body (depths see Table 1), facultative anaerobic, brackish (8-16\%); Type material: iconotypes: Figure 6B and insertion down left; fixed and embedded specimens (hapantotypes) are deposited at the Oberösterreichische Landesmuseum in Linz, Austria (inventory number 2012/120); live strains (paratypes) are held as clonal cultures (strains IOW73-75) in the laboratory of the Leibniz Institut for Baltic Sea Research in Rostock-Warnemünde; Etymology: minima, due to the small cell size.

Remarks. The species described here could easily be separated from C. gracilis based on their size (2-4.5 $\mu \mathrm{m}$ length for IOW73 and IOW94 vs. 4-8 $\mu \mathrm{m}$ for $C$. gracilis), the shorter flagellum (max. $8 \mu \mathrm{m}$ vs. $8-20 \mu \mathrm{m}$ for C. gracilis), the flagellar root microtubules (organised in one row vs. 2-3 rows for C. gracilis $[28,30,31])$ and the shape of mitochondrial cristae. C. balthica differs from C. minima by possessing intracellular bacteria and based on $18 \mathrm{~S}$ and partial 28S rRNA gene sequences. No 18S rRNA sequence of Codosiga cultures exists (as discussed in [6]), but the clustering of the 28S rRNA tree supports the separation of both our strains from their nearest neighbour, C. gracilis (Figure 4). Both species descriptions are deposited in ZooBank under urn:lsid:zoobank.org:act:8EA52C91-58CE4FF9-9007-AC9DED267DD6 (C. minima) and urn:lsid:zoobank.org:act:DF26A642-BD7A-4819-BE8C-40B01A1E7971 (C. balthica).

\section{Discussion}

Putative anaerobic choanoflagellate species have been occasionally detected using microscopical methods [32,33]. For example, Diaphanoeca sp. and Acanthocorbis sp. were found in fixed samples from suboxic to anoxic/sulfidic waters of the Mariager Fjord [9] but did not grow in anaerobic incubations. In contrast, Codosiga species had not been described to date for hypoxic environments.

As shown here, aloricate choanoflagellates (including choanoflagellate cells that show no lorica under epifluorescence microscope) in general are numerically important members of the Baltic redoxcline protistan community with a peak at the suboxic zone above the chemocline. Their relative abundance was higher in Gotland Deep (up to 20 to $30 \%$ of total HNF cell-counts) than in Landsort Deep (up to 5\%). The Gotland Deep is characterized by periodical small-scale mixing events $[34,35]$ and frequent lateral intrusions of oxygenated water $[20,36]$, which lead to a less stable redoxcline than in Landsort Deep. Nevertheless, both deeps are rather similar concerning salinity, oxygen and sulfide content and should principally be colonized by both species if they are tolerant to anoxic and sulfidic conditions and it requires more samplings to reveal consistent differences in the spatial and temporal distribution of the two species.

The single cell isolations, conducted in 2005, gave us the opportunity to isolate and describe strains from these abundant choanoflagellates. On the same cruise, redoxcline samples from Gotland Deep were collected for RNA-based clone library investigations of oxic-anoxic transition zone and sulfidic water depths [20] which resulted in several $18 \mathrm{~S}$ rRNA clonal sequences highly similar to our C. balthica isolate (see framed clade in Figure 3). RNA- 


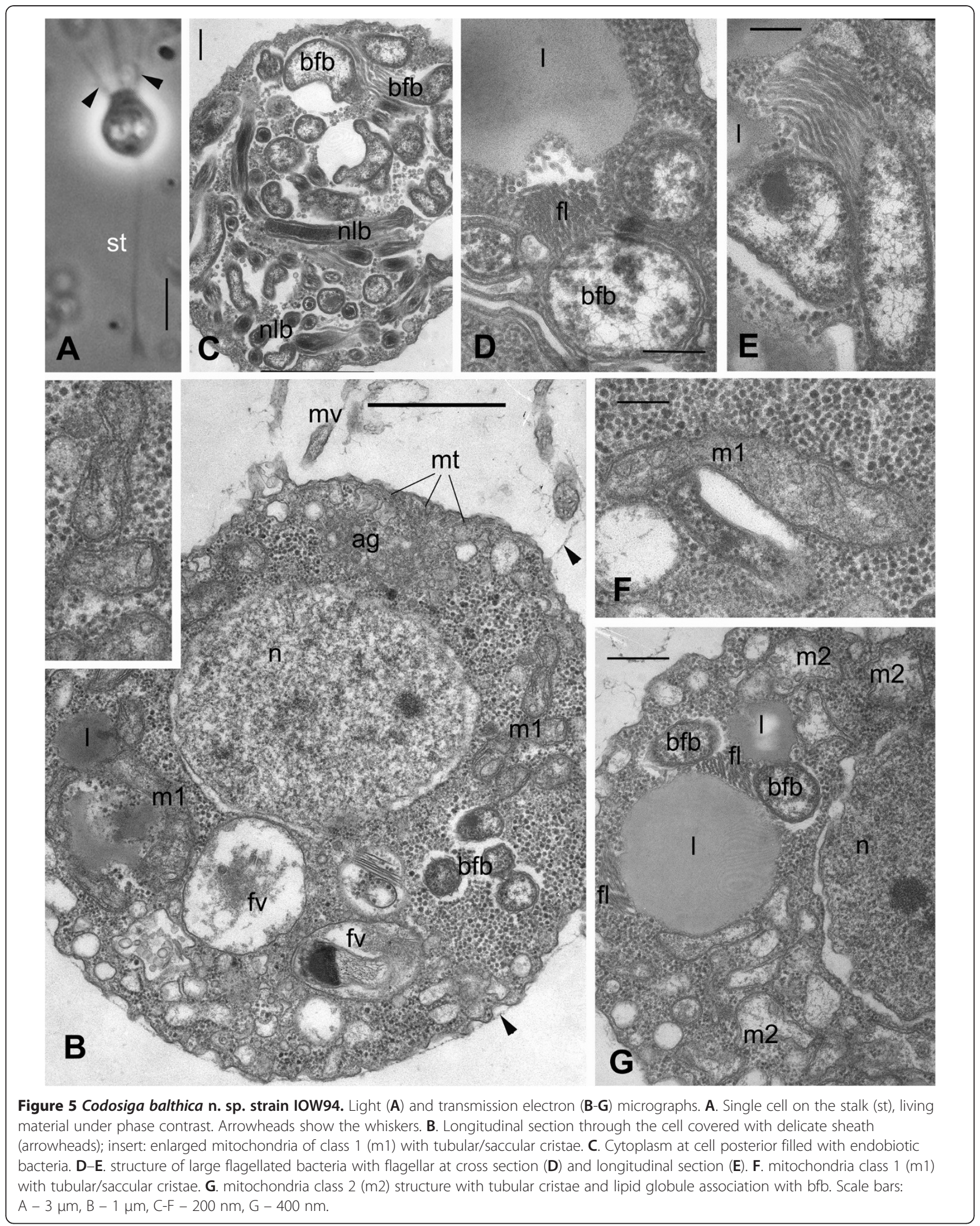




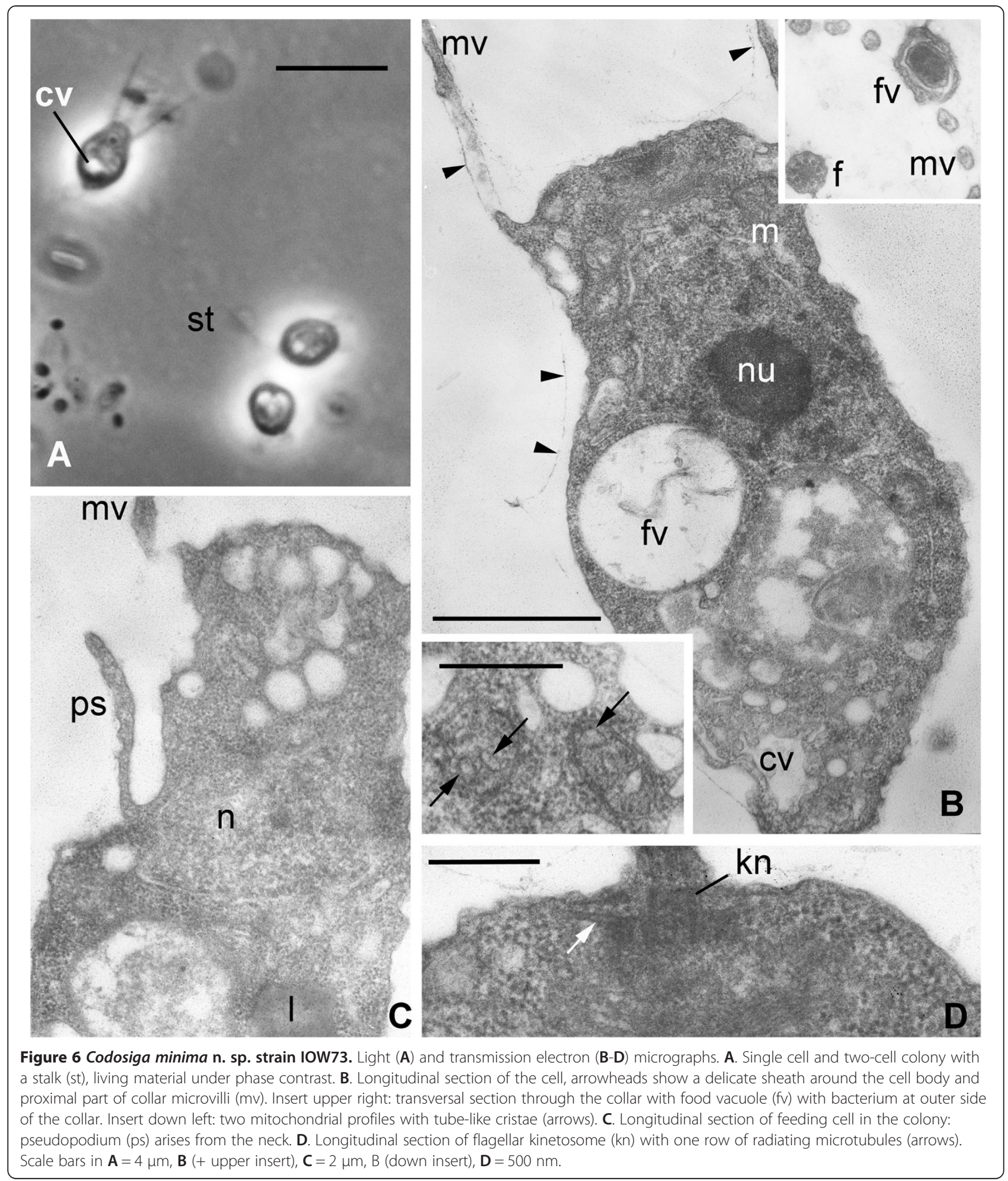

based clone libraries can be influenced by different numbers of ribosomal RNA molecules depending on cell size, trophic state or rather metabolic activity. Because of the small cell size of Codosiga spp. we would expect that its contribution in clone libraries of the total protistan community is only minor. However, the high amount of clonal sequences closely related to C. balthica found by Stock et al. [20] (11\% and 4\% in the library of the oxicanoxic transition zone and the sulfidic zone, respectively) indicates in our opinion a high abundance of the 
Table 1 Isolated strains, with the corresponding isolation depths and physico-chemical data (Gotland (G) and Landsort Deeps (L), central Baltic Sea) and GenBank accession numbers for partial gene sequences generated in this study

\begin{tabular}{|c|c|c|c|c|}
\hline Species & Codosiga balthica & Codosiga & & \\
\hline Detected via & Clone library $\left(\mathbf{G}^{1}\right)$ DGGE $\left(\mathbf{G}^{2}, \mathbf{L}^{3}\right)$ Isolation $\left(\mathbf{G}^{4}\right)$ & Isolation ( & & \\
\hline Strain & IOW94 & IOW73 & IOW74 & IOW75 \\
\hline Station & $271(\mathbf{G})$ & $271(\mathbf{G})$ & $271(\mathbf{G})$ & $284(\mathbf{L})$ \\
\hline Depth [m] & 206 & 150 & 208 & 260 \\
\hline $\mathrm{O}_{2}[\mu \mathrm{M}]$ & 0.85 & 1.57 & 0.48 & 4.23 \\
\hline $\mathrm{H}_{2} \mathrm{~S}[\mu \mathrm{M}]$ & 0.13 & 0.25 & 1.77 & n.det. \\
\hline $18 \mathrm{~S}$ rRNA & JQ034424 & JQ034422 & n.sub. & n.sub. \\
\hline $28 \mathrm{~S}$ rRNA & JQ034425 & JQ034423 & n.det. & n.det. \\
\hline
\end{tabular}

(1Stock et al. 2009 [20]; ${ }^{2}$ Weber 2008 [37]; ${ }^{3}$ Anderson et al. [38] (in revision); ${ }^{4}$ this study; n.det., not detected; n.sub., not submitted to GenBank).

corresponding cells at the sampling site. The $18 \mathrm{~S}$ rRNA sequence of $C$. balthica also was reported via DGGE fingerprint techniques from the same habitat in 2007. The relevant DGGE band was detected only in water depths below the chemocline, representing anoxic/sulfidic water layers until concentrations of $11 \mu \mathrm{M}$ hydrogen sulfide [37]. These data correspond to the vertical distribution of Codosiga spp. at the sampling time (Figure 1), where they were mainly found in anoxic depths. Additionally, an identical sequence was detected from a DGGE fingerprint from Landsort Deep permanent redoxcline collected at the oxic/ anoxic interface in 2011 [38]. Overall, our results indicate that at least $C$. balthica is a permanent and prominent member of the protistan community of Gotland and Landsort Deep redoxclines.

In contrast to this taxon, C. minima was isolated for cultivation from three different redoxcline samples during a cruise in 2005. Two of these cultures were obtained from Gotland Deep (strain IOW73, $150 \mathrm{~m}$; strain IOW74, $208 \mathrm{~m}$ ) while the third isolate came from Landsort Deep (strain IOW75, $260 \mathrm{~m}$; identity seen at an 18S rRNA sequence level, see Table 1). In contrast to C. balthica, no closely related environmental sequence for $C$. minima was found in GenBank, which is typical for several isolated and cultivated protistan taxa with presumably only minor ecological relevance [39,40].

The general ultrastructure of both species described here is similar to that of other investigated "naked" craspedids [41-43]. However, the singular adaptation of their mitochondria, and, in the case of C. balthica, the acquisition of intracellular bacteria, are very likely strategies gained both species to deal with oxygen depletion.

The cells of $C$. minima have mitochondria with tubular but developed cristae, while C. balthica has mitochondria of two types: $\mathrm{m} 1$ and $\mathrm{m} 2$ (see Figure 5). Both types of mitochondria have predominantly cristae with a tubular shape, but the type $\mathrm{m} 2$ shows a reduced number of cristae and an electron translucent matrix. Tubular cristae have never been found before in choanoflagellates, even in specially designed experiments to change the shape of mitochondrial cristae with steroids, conducted unsuccessfully on a $M$. ovata culture [44]. Mitochondria with reduced number of cristae were recently classified as anaerobically functioning mitochondria of the class 2 [45]. Such mitochondria have a reduced enzyme inventory with regard to oxidative phosphorylation and are able to use other electron acceptors than oxygen (e.g. fumarate or nitrate). The routine growth of our strains under normoxic circumstances in the laboratory shows that the mitochondria of both species can use oxygen without any difficulty. It is not clear at the moment whether the two types/classes of mitochondria in C. balthica coexist permanently or if some of the mitochondria transformed into aerobically functioning ones (class 1 according to Müller et al. [45]) during the cultivation under oxic condition. Higher numerical reduction of cristae (oxygen consuming components) in C. balthica mitochondria class 2 and the abundance of this taxon in oxygen depleted waters support the possibility to use other electron acceptors in response to decreasing oxygen levels in the environment.

Prokaryotic endosymbionts are common in protists, particularly in ciliates and dinoflagellates $[46,47]$, but had never been observed previously for choanoflagellates [41-43]. Anaerobic ciliates often harbour methanogenic archaeans in close connection to their hydrogenosomes, and Eubacteria without connections to the hydrogenosomes $[48,49]$. C. balthica clearly does not possess hydrogenosomes and its endobionts are of bacterial nature as recognizable by the second enveloping membrane instead of a cell wall like archaeans (Figure 5D). Interestingly, the intracellular prokaryotes were not lost during nearly seven years of cultivation under oxic conditions, indicating that this is likely an obligate symbiosis for the choanoflagellate. Similar to observations in anaerobic ciliates, the endobionts likely support the choanoflagellate host (C. balthica) during anaerobic metabolism and thus allowed them to colonize oxygen depleted zones that supply high food availability. However, at this time we can not further specify the identity and role of these intracellular prokaryotes. 
As noted in the introduction, environmental choanoflagellate sequences are typical constituents of pelagic redoxcline protist communities and have been frequently detected in hypoxic waters via clone libraries [18-20,50,51]. One environment in particular is worthy of mention: although the Cariaco Basin is globally the most comprehensively sampled redoxcline environment (nearly 7,000 entries in GenBank of partial clonal 18S rRNA gene sequences for this habitat; e.g., [50,52,53]), no sequences belonging to $C$. balthica or C. minima have been found there. This could be deeply rooted in methodological limitations (e.g. different primers used for RNA or DNA templates). Alternatively, the higher salinity of the Cariaco Basin, or other physico-chemical or hydrological parameters, could exclude the two Baltic Codosiga species from this environment with fully saline conditions. However, these species seem to be relatively insensitive to salinity variations and are highly tolerant to the presence of oxygen and sulfide. They were able to grow in culture at $8 \%$ (this study) and one sequence related to strain $C$. balthica comes from deeper hypoxic water layers of the Framvaren Fjord at about 25\%, [18]. Thus, the possibility that these species represent endemic taxa of the Baltic Sea region should be taken into consideration and will be tested in further studies.

\section{Conclusions}

Both isolated species described here, C. minima and C. balthica, were found within suboxic to anoxic water layers, in the latter case using different approaches and in several years. The species are of interest due to their habitat, from which no choanoflagellate cultures could be obtained yet, their unusual mitochondrial cristae and presence of intracellular prokaryotes in one species. Our isolation effort is important in view of the complexity of isolation and cultivation of choanoflagellates species [5] and of protists that can survive in hypoxic environments in general. The novel C. balthica is ecologically relevant component of the protist community at the sampling sites tested. With its interior (derived mitochondria, prokaryotes), at least $C$. balthica is potentially able to outcompete less adaptable heterotrophic nanoflagellates and to become abundant in hypoxic parts of the Baltic Sea. Preliminary investigations have shown that C. balthica is able to grow successfully under suboxic conditions in the laboratory, but not C. minima (M. Marcuse, C. Wylezich \& K. Jürgens, unpublished results). Our next challenges would be (1) to identify and characterize the functional role of the intracellular prokaryotes of C. balthica, and (2) to determine the quantitative contribution of both species to the Baltic protistan community via fluorescently labelled specific probes. Moreover, both cultivated species are ideal model organisms for future studies on temporary anaerobic metabolism using derived mitochondria.

\section{Methods \\ Sampling, isolation/cultivation and counting of choanoflagellates}

Strains of the newly described Codosiga spp. were obtained from untreated plankton samples taken in the central Baltic Sea at the Gotland (IOW-station 271; $57^{\circ}$ $19.2^{\prime} \mathrm{N} ; 20^{\circ} 03^{\prime} \mathrm{E}$ ) and the Landsort Deep (IOW-station 284; $58^{\circ} 35.0^{\prime} \mathrm{N} ; 18^{\circ} 14.0^{\prime} \mathrm{E}$ ) in May 2005 during an expedition with the RV Alkor. Clonal cultures were obtained from a single cell shortly after sampling, which was isolated using a micromanipulator fitted with glass micropipette [54]. The cultures were deposited as part of the IOW culture collection, and were routinely kept in sterile 50-ml tissue culture flasks (Sarstedt, Nümbrecht, Germany) in F2 medium [55] (salinity 8-12\%o) on a mixture of bacteria grown on a wheat grain. Altogether four choanoflagellate cultures could be established (Table 1).

Samples for cell-counts of HNF were obtained on board the RV Poseidon in August 2008 (Gotland Deep) and the RV Maria S. Merian in September 2009 (Gotland and Landsort Deep). Water from different depths (GD 2008: 114-137 m, GD 2009: 90-140 m, LD 2009: 70-120 m) was collected in $10 \mathrm{l}$ free-flow bottles attached to a conductivity, temperature and depth rosette (CTD) with a coupled oxygen sensor. In all cases, oxygen and hydrogen sulfide were measured immediately on board according to standard methods [56]. In order to avoid potential oxygen contamination during emptying of the free-flow bottles, for experimental purposes only the bottom $5 \mathrm{l}$ of water from $10 \mathrm{l}$ free-flow bottles was employed.

\section{Molecular biological investigations}

DNA was extracted from cells harvested from $20-30 \mathrm{ml}$ of dense cultures (8000 g, $20 \mathrm{~min}, 4^{\circ} \mathrm{C}$ ) using a CTAB extraction as described previously [57]. The $18 \mathrm{~S}$ rRNA gene was amplified by polymerase chain reaction (PCR) using eukaryotic specific primers 18SFor-n2 (5'- GAT CCT GCC AGT AGT CAT AYG C - $3^{\prime}$ ) and 18SRev-Ch ( $5^{\prime}$ - TCC TTC TGC AGG TTC ACC TAC GG - 3'). The mixture containing $0.1 \mathrm{mM}$ of each primer, $200 \mathrm{mM}$ dNTPs, $10 \mathrm{mM}$ Tris pH 8.3, $1.5 \mathrm{mM} \mathrm{MgCl} 2,50 \mathrm{mM} \mathrm{KCl}$, and 1 unit of Taq DNA polymerase (Fermentas) was heated to $95^{\circ} \mathrm{C}$ for $2 \mathrm{~min}$, and the $18 \mathrm{~S}$ rRNA gene was amplified in 35 cycles of $95^{\circ} \mathrm{C}$ for $30 \mathrm{~s}, 52^{\circ} \mathrm{C}$ for $45 \mathrm{~s}$, and $72^{\circ} \mathrm{C}$ for $2 \mathrm{~min}$, followed by $10 \mathrm{~min}$ at $72^{\circ} \mathrm{C}$. PCR products were purified with the Nucleospin II Kit (Machery Nagel). Sequencing was carried out by a company (Qiagen) with the primers used for PCR and four different internal sequencing primers (590F: $5^{\prime}$ - CGG TAA TTC CAG CTC CAA TAG C - 3', 600R: 5' - GCT ATT GGA GCT GGA ATT ACC G - 3', 1280F: 5'- TGC ATG GCC GTT CTT 
AGT TGG TG - 3', 1300R: 5' - CAC CAA CTA AGA ACG GCC ATG C $-3^{\prime}$ ). The $28 \mathrm{~S}$ rRNA was amplified as described above with extended elongation time (3 $\mathrm{min})$ annealing of $48^{\circ} \mathrm{C}$ using primers fw1 ( $5^{\prime}$ - AGC GGA GGA AAA GAA ACT A - $3^{\prime}$ ) and 20R (5'- GAG AGT CAT AGT TAC TCC C - 3', kindly provided by C. Berney). The purified PCR products were partially sequenced by use of primers 1274 (5' - GAC CCG TCT TGA AAC ACG GA - 3'), D5-Rev2 (5'- GGC AGG TGA GTT GTT ACA - $3^{\prime}$, all given in [57]), and the newly designed primer D2D3-Rev ( $5^{\prime}$ - GAC TCC TTG GTC CGT GTT TC - $\left.3^{\prime}\right)$.

Obtained sequences were checked and corrected using Bioedit [58]. Genetic distances were calculated with Mega [59]. Sequences were aligned together with other sequences retrieved from GenBank using Clustal_X program [60]. Afterwards, the alignments were edited manually. Two data sets of the sequence alignments were created for the $18 \mathrm{~S}$ and $28 \mathrm{~S}$ rRNA gene sequences. The 18S rRNA data set contains 1,623 aligned nucleotide positions, and the 28S rRNA alignmet excluding the high divergent D2 region was 1,497 positions in length. We used MrBayes [61] and PhyML 3.0 (http://www. atgc-montpellier.fr/phyml/ [62]) for the phylogenetic analyses. The analyses were done using the GTR model of substitution [63] and gamma-shaped distribution of rates of substitution among sites with eight rate categories. The Bayesian analysis was performed for 1,000,000 generations and sampled every 100 generations for four simultaneous MCMC chains (born-in = 2,500). For the maximum likelihood analysis all model parameters were estimated from the data set. To estimate branch support, we performed 500 bootstrap replicates for maximum likelihood analyses. Phylogenetic reconstruction based on the partial 28S rRNA gene we chose choanoflagellate sequences from GenBank that cover the complete length of sequence fragments generated in this study.

\section{Microscopical investigations}

For light microscopy observations of living cells a DM 2500 microscope (Leica) was used. For electron microscopy, the cultures were adapted to a salinity of $8 \%$ to simplify the fixation protocol. The cell-pellet was fixed, on ice in the dark for $30 \mathrm{~min}$, with a cocktail containing $2 \%$ glutaraldehyde and $1 \%$ osmium tetroxide in F2 medium, buffered with $0.05 \mathrm{M}$ cacodilate to $\mathrm{pH}$ 7.2. After dehydration in an alcohol series the pellet was embedded in Epon/ Araldite resin, sectioned with a glass knife, and stained with uranyl acetate and lead citrate. The sections were observed at $80 \mathrm{Kv}$, under an EM Margani FI 268 electron microscope equipped with digital camera (Olympus Megaview III).

For flagellate identification in 2005, a combination of live observations and scanning electron microscopy was employed. For live samples, sea water was concentrated by reverse filtration $(0.2 \mu \mathrm{m}$ membrane filter; Millipore
GmbH, Schwalbach, Germany) in a hermetic box with a nitrogen atmosphere at $4^{\circ} \mathrm{C}$. Concentrated samples were then placed inside a $1 \mathrm{ml}$ transparent glass chamber, hermetically sealed with a cover slip, and observed, directly on board, using phase contrast at 360X and 630X under an Axiovert $40 \mathrm{CFL}$ inverted microscope (Carl Zeiss MicroImagimg $\mathrm{GmbH}$ ). Additionally, individual flagellate cells were isolated by means of a specially constructed micropipette [54], and cultured in 96-well plates or petri-dishes, with sterile autoclaved Baltic Sea water as medium and Pseudomonas putida MM-1 as food source. Dried whole mount preparations of these flagellates were later examined with a JEM-1011 transmission electron microscope (JEOL Ltd.; Tokyo, Japan) as previously described [64].

For HNF cell counts in 2008 and 2009, $100 \mathrm{ml}$ samples were fixed with a final concentration of $1 \%$ particle free formaldehyde in brown glass bottles, at $4^{\circ} \mathrm{C}$, between 2 and $24 \mathrm{~h}$. Subsamples were filtered onto black polycarbonate filters $(0.8 \mu \mathrm{m}$ pore-size; $25 \mathrm{~mm}$ diameter; Whatman $\mathrm{GmbH}$, Dassel, Germany), which were stored at $-20^{\circ} \mathrm{C}$ or $-80^{\circ} \mathrm{C}$. Filters were later stained with DAPI at a concentration of $0.01 \mathrm{mg} \mathrm{ml}^{-1}$, mounted, and observed under a Zeiss Axioskop 2 mot plus epifluorescence microscope (Carl Zeiss MicroImagimg GmbH, Gottingen, Germany). A minimum of 100 cells per filter were counted at 630X using filter set 02 (Carl Zeiss MicroImagimg $\mathrm{GmbH}$ ). Aloricate choanoflagellates were clearly distinguishable and therefore counted as a separate group.

\section{Abbreviations \\ 18 rRNA: Small subunit of ribosomal RNA; 28 rRNA: Large subunit of ribosomal RNA; ag: Golgi apparatus; bfb: Endobiotic big flagellated bacteria; CTAB: Cetyl trimethyl ammonium bromide; cv: Contractile vacuole; DGGE: Denaturing gradient gel electrophoresis; EM: Electron microscopy; f: Eukaryotic flagellum; fl: Prokaryotic flagella; fv: Food vacuole; GD: Gotland Deep; GTR: General time reversible; HNF: Heterotrophic nanoflagellates; kn: Flagellar kinetosome; I: Lipid droplet; LD: Landsort Deep; LM: Light microscopy; m: Mitochondrion; m1: Mitochondrium type 1; m2: Mitochondrium type 2; MCMC: Markov Chain Monte Carlo; mt: Microtubules of flagellar root system; mv: Microvilli of the collar; n: Nucleus; nlb: Narrow long endobiotic bacteria; nu: Nucleolus; ps: Food pseudopodium; st: Stalk.}

\section{Competing interests}

The authors declare that they have no competing interests.

\section{Authors' contributions}

CW generated the $18 \mathrm{~S}$ and $28 \mathrm{~S}$ rRNA gene sequences, carried out the phylogenetic analyses and wrote the first draft of the paper; SK generated the LM and TEM data and interpreted these data and contributed to writing the manuscript; APM collected and isolated the specimens for cultivation, and analysed its vertical distribution in 2005; RA did sampling, counting and analyzing of HNF and choanoflagellates in 2008 and 2009 and contributed to writing the manuscript; $\mathrm{KJ}$ funded the flagellate collection, organized the cruises and contributed analytic tools; all authors have read, edited and approved the final manuscript.

\section{Acknowledgements}

We are indebted to Ronja Breitkopf and Bärbel Buuk for excellent technical support, as well as Dr. Konstantin Khalturin for transport of cultured strains to St. Petersburg. Sincere thanks are given to Dr. Cedric Berney for provision of 
a primer sequence. We would like to thank Olivia Diehr and Jürene BrunsBischoff for their sedulous support in providing a lot of references. We are grateful to Felix Weber for helpful discussions of the data and the manuscript. This work was funded by grant from the German Science Foundation (DFG) (JU 367/11-1) and the RAS Presidium program "Problems of life origin and biosphere development".

\section{Author details}

'IOW-Leibniz Institute for Baltic Sea Research Warnemünde, Rostock, Germany. ${ }^{2}$ Zoological Institute RAS and St. Petersburg State University, St. Petersburg, Russia. ${ }^{3}$ Institute for the Biology of Inland Waters, Russian Academy of Sciences, Borok, Russia.

Received: 24 August 2012 Accepted: 8 November 2012 Published: 21 November 2012

\section{References}

1. Adl SM, Simpson AGB, Farmer M, Andersen RA, Anderson OR, Barta JR, Bowser S, Brugerolle G, Fensome RA, Fredericq S, James T, Karpov S, Kugrens P, Krug J, Lane CE, Lewis LA, Lodge J, Lynn DH, Mann DG, McCourt RM, Mendoza L, Moestrup Ø, Mozley-Standridge SE, Nerad TA, Shearer CA, Smirnov AV, Spiegel FW, Taylor MJR: The new higher level classification of eukaryotes with emphasis on the taxonomy of protists. J Eukaryot Microbiol 2005, 52:399-451.

2. King N, Carroll SB: A receptor tyrosine kinase from choanoflagellates: molecular insights into early animal evolution. Proc Natl Acad Sci USA 2001, 98:15032-15037.

3. Steenkamp ET, Wright J, Baldauf SL: The protistan origins of animals and fungi. Mol Biol Evol 2006, 23:93-106.

4. Ruiz-Trillo I, Lane CE, Archibald JM, Roger AJ: Insights into the evolutionary origin and genome architecture of the unicellular opisthokonts Capsaspora owczarzaki and Sphaeroforma arctica. J Eukaryot Microbiol 2006, 53:379-384.

5. Carr M, Leadbeater BSC, Hassan R, Nelson M, Baldauf SL: Molecular phylogeny of choanoflagellates, the sister group to Metazoa. Proc Natl Acad Sci USA 2008, 105:16641-16646.

6. Nitsche F, Carr M, Arndt H, Leadbeater BSC: Higher level taxonomy and molecular phylogenetics of the Choanoflagellatea. J Eukaryot Microbiol 2011, 58:452-462.

7. Vørs N, Buck KR, Chavez FP, Eikrem W, Hansen LE, Østergaard JB, Thomsen HA: Nanoplankton of the equatorial Pacific with emphasis on the heterotrophic protists. Deep-Sea Res II 1995, 42:585-602.

8. Leakey RJG, Leadbeater BSC, Mitchell E, McCready SMM, Murray AWA: The abundance and biomass of choanoflagellates and other nanoflagellates in waters of contrasting temperature to the north-west of South Georgia in the Southern Ocean. Europ J Protistol 2002, 38:333-350.

9. Fenchel T, Bernard C, Esteban G, Finlay BJ, Hansen PJ, Iversen N: Microbial diversity and activity in a Danish fjord with anoxic deep water. Ophelia 1995, 43:45-100.

10. Anderson R: From single species to the community level: exploring underresearched avenues in protist ecology and protist-prokaryote interactions, PhD Thesis. Rostock: University of Rostock and Leibniz-Institut for Baltic Sea Research Warnemünde; 2012.

11. Massana R, Guillou L, Díez B, Pedrós-Alió C: Unveiling the organisms behind novel eukaryotic ribosomal DNA sequences from the ocean. Appl Environ Microbiol 2002, 68:4554-4558.

12. Vaulot $D$, Eikrem $W$, Viprey $M$, Moreau H: The diversity of small eukaryotic phytoplankton (<3 um) in marine ecosystems. FEMS Microbiol Rev 2008, 32:795-820.

13. Yubuki N, Edgcomb VP, Bernhard JM, Leander BS: Ultrastructure and molecular phylogeny of Calkinsia aureus: Cellular identity of a novel clade of deep-sea euglenozoans with epibiotic bacteria. BMC Microbiol 2009, 9:16.

14. Yabuki A, Ishida K: Mataza hastifera n. g., n. sp.: A possible new lineage in the Thecofilosea (Cercozoa). J Eukaryot Microbiol 2011, 58:94-102.

15. del Campo J, Not F, Forn I, Sieracki ME, Massana R: Taming the smallest predators of the ocean. ISME J 2012, doi:10.1038/ismej.2012.85.

16. del Campo J, Massana R: Emerging diversity within chrysophytes, choanoflagellates and bicosoecids based on molecular surveys. Protist 2011, 162:435-448.

17. Weber F, del Campo J, Wylezich C, Massana R, Jürgens K: Unveiling trophic functions of uncultured protist taxa by incubation experiments in the brackish Baltic Sea. PLoS One 2012, 7:e41970.
18. Behnke A, Bunge J, Barger K, Breiner HW, Alla V, Stoeck T: Microeukaryote community patterns along an $\mathrm{O}_{2} / \mathrm{H}_{2} \mathrm{~S}$ gradient in a supersulfidic anoxic fjord (Framvaren, Norway). Appl Environ Microbiol 2006, 72:3626-3636.

19. Alexander E, Stock A, Breiner H-W, Behnke A, Bunge J, Yakimov MM, Stoeck T: Microbial ekaryotes in the hypersaline anoxic L'Atalante deep-sea basin. Environ Microbiol 2009, 11:360-381.

20. Stock A, Jürgens K, Bunge J, Stoeck T: Protistan diversity in suboxic and anoxic waters of the Gotland Deep (Baltic Sea) as revealed by $18 \mathrm{~S}$ rRNA clone libraries. Aquat Microb Ecol 2009, 55:267-284.

21. Setälä O: Ciliates in the anoxic deep water layer of the Baltic. Arch Hydrobiol 1991, 122:483-492.

22. Detmer AE, Giesenhagen HC, Trenkel VM, Auf Dem Venne H, Jochem FJ: Phototrophic and heterotrophic pico- and nanoplankton in anoxic depths of the central Baltic Sea. Mar Ecol Prog Ser 1993, 99:197-203.

23. Anderson $R$, Winter $C$, Jürgens $K$ : Relevance of protist grazing and viral lysis as prokaryotic mortality factors for Baltic Sea oxic-anoxic interfaces. Mar Ecol Prog Ser 2012, 467:1-14.

24. Labrenz $M$, Jost $G$, Jürgens $K$ : Distribution of abundant prokaryotic organisms in the water column of the central Baltic Sea with an oxic-anoxic interface. Aquat Microb Ecol 2007, 46:177-190.

25. Labrenz M, Sintes E, Toetzke F, Zumsteg A, Herndl GJ, Seidler M, Jürgens K: Relevance of a crenarchaeotal subcluster related to Candidatus Nitrosopumilus maritimus to ammonia oxidation in the suboxic zone of the central Baltic Sea. ISME J 2010, 4:1496-1508.

26. Glaubitz S, Lueders T, Abraham WR, Jost G, Jürgens K, Labrenz M: ${ }_{13} \mathrm{C}$ isotope analyses reveal that chemolithoautotrophic Gamma- and Epsilonproteobacteria feed a microbial food web in a pelagic redoxcline of the central Baltic Sea. Environ Microbiol 2009, 11:326-337.

27. der Staay SY M-V, De Wachter R, Vaulot D: Oceanic $18 \mathrm{~S}$ rDNA sequences from picoplankton reveal unsuspected eukaryotic diversity. Nature 2001, 409:607-610.

28. Karpov SA: Ultrathin structure of choanoflagellate Monosiga ovata. Tsitologia 1982, 24:400-404. in Russian.

29. Karpov SA: Modes of nutrition in choanoflagellates. Vestnik LGU 1982 21:91-94. in Russian.

30. Karpov SA: Ultrathin structure of choanoflagellate Sphaeroeca volvox. Tsitologia 1981, 23:991-996. in Russian.

31. Leadbeater BSC, Morton C: A microscopical study of a marine species of Codosiga James-Clark (Choanoflagellata) with special reference to the ingestion of bacteria. Biol J Limn Soc 1974, 6:337-347.

32. Fenchel T, Finlay BJ: Ecology and Evolution in anoxic worlds, Oxford Series in Ecology and Evolution. Oxford: Oxford University Press; 1995.

33. Bernard C, Simpson AGB, Patterson DJ: Some free-living flagellates from anoxic sediments. Ophelia 2000, 52:113-142.

34. Lass HU, Prandke H, Liljebladh B: Dissipation in the Baltic proper during winter stratification. J Geophys Res 2003, 108:3187.

35. Reissmann JH, Burchard H, Feistel R, Hagen E, Lass HU, Mohrholz V, Nausch G, Umlauf L, Wieczorek G: Vertical mixing in the Baltic Sea and consequences for eutrophication - A review. Prog Oceanogr 2009, 82:47-80.

36. Feistel R, Nausch C, Heene T, Piechura J, Hagen E: Evidence for a warm water inflow into the Baltic Proper in summer 2003. Oceanolgia 2004 46:581-598.

37. Weber F: Verteilung und Diversität von Protisten in der pelagischen Redoxkline der zentralen Ostsee, Diploma Thesis. Rostock: University of Rostock and Leibniz-Institut for Baltic Sea Research Warnemünde; 2008.

38. Anderson R, Wylezich C, Glaubitz S, Labrenz M, Jürgens K: Impact of protist grazing on a key bacterial group for biogeochemical cycling in Baltic Sea pelagic oxic / anoxic interfaces. Environ Microbiol in press, doi:10.1111/ 1462-2920.12078.

39. Guillou G, Moon-van Der Staay SY, Claustre H, Partensky F, Vaulot D: Diversity and abundance of Bolidophyceae (Heterokonta) in two oceanic regions. Appl Environ Microbiol 1999, 65:4528-4536.

40. Lim EL, Dennett MR, Caron DA: The ecology of Paraphysomonas imperforate based on studies employing oligonucleotide probe identification in costal water samples and enrichment cultures. Limnol Oceanogr 1999, 44:37-51.

41. Karpov SA, Zhukov BF: Phylum Choanomonada. In Protista. 1. Handbook of Zoology. Edited by Karpov SA. St. Petersburg: Nauka; 2000:321-336. in Russian.

42. Leadbeater BSC, Thomsen HA: Order Choanoflagellida. In An Illustrated Guide to the Protozoa. 2nd edition. Edited by Lee JJ, Leedale GF, Bradbury P. Kansas USA: Society of Protozoologists; 2000:14-39. 
43. Zhukov BF, Karpov SA: Freshwater choanoflagellates. Leningrad: Nauka; 1985 in Russian.

44. Fokin SI, Goodkov AV, Karpov SA, Seravin LN: The effect of some steroids on the mitochondria ultrastructure of amoebae, flagellates and ciliates (Protista). Tsitologia 1993, 35:44-48. in Russian.

45. Müller M, Mentel M, van Hellemond JJ, Henze K, Woehle C, Gould SB, Yu RY van der Giezen M, Tielens AGM, Martin WF: Biochemistry and evolution of anaerobic energy metabolism in eukaryotes. Microbiol Mol Biol Rev 2012, 76:444-495.

46. Ossipov DV, Karpov SA, Smirnov AV, Rautian MS: Peculiarities of the symbiotic systems of protists with diverse patterns of cellular organisation. Acta Protozool 1997, 37:3-22.

47. Nowack EC, Melkonian M: Endosymbiotic associations within protists. Phil Trans R Soc Lond B 2010, 365:699-712.

48. Clarke KJ, Finlay BJ, Esteban G, Guhl BE, Embley TM: Cyclidium porcatum $\mathrm{n}$. sp.: free-living anaerobic scuticociliate containing a stable complex of hydrogenosomes, Eubacteria and Archaeobacteria. Europ J Protistol 1993, 29:262-270

49. Shinzato N, Watanabe I, Meng XY, Sekiguchi Y, Tamaki H, Matsui T, Kamagata Y: Phylogenetic analysis and fluorescence in situ hybridization detection of archaeal and bacterial endosymbionts in the anaerobic ciliate Trimyema compressum. Microb Ecol 2007, 54:627-636.

50. Edgcomb V, Orsi W, Bunge J, Jeon SO, Christen R, Leslin C, Holder M, Taylor GT, Suarez P, Varela R, Epstein S: Protistan microbial observatory in the Cariaco Basin, Caribbean. I. pyrosequencing vs sanger insights into species richness. ISME J 2011, 5:1344-1356.

51. Wylezich $C$, Jürgens $K$ : Protist diversity in suboxic and sulfidic waters of the Black Sea. Environ Microbio/ 2011, 13:2939-2956.

52. Stoeck T, Taylor GT, Epstein SS: Novel eukaryotes from the permanently anoxic Cariaco Basin (Caribbean Sea). Appl Environ Microbiol 2003, 69:5656-5663.

53. Stoeck T, Hayward B, Taylor GT, Varela R, Epstein SS: A multiple PCR-primer approach to access the microeukaryotic diversity in environmental samples. Protist 2006, 157:31-43.

54. Zhukov BF, Balonov IM: The modernizated micropipette for isolation of microorganisms. Biol Inland Water: Inform Bull 1979, 42:9-11.

55 Guillard R, Ryther JH: Studies of marine planktonic diatoms. I. Cyclotella nana Husted and Detonula confervacea (Cleve) Gran ("F" medium). Can J Microbiol 1962, 8:229-239.

56. Grasshoff K, Erhardt M, Kremling K: Methods of seawater analysis. Vol. Verlag Chemie: Weinheim; 1983.

57. Wylezich C, Nies G, Mylnikov AP, Tautz D, Arndt H: An evaluation of the use of the LSU rRNA D1-D5 domain for DNA-based taxonomy of eukaryotic protists. Protist 2010, 161:342-352.

58. Hall TA: BioEdit: a user-friendly biological sequence alignment editor and analysis program for Windows 95/98/NT. Nucleic Acids Res Symp Ser 1999, 41:95-98.

59. Kumar S, Tamura K, Nei N: MEGA3: Integrated software for molecular evolutionary genetics analysis and sequence alignment. Brief Bioinform 2004, 5:150-163.

60. Thompson JD, Gibson TJ, Plewniak F, Jeanmougin F, Higgins DG: The ClustalX windows interface: flexible strategies for multiple sequence alignment aided by quality analysis tools. Nucleic Acids Res 1997, 24:4876-4882.

61. Huelsenbeck JP, Ronquist F, Nielsen R, Bollback JP: Bayesian inference of phylogeny and its impact on evolutionary biology. Science 2001, 294:2310-2314.

62. Guindon S, Gascuel O: A simple, fast, and accurate algorithm to estimate large phylogenies by maximum likelihood. Syst Biol 2003, 52:696-704.

63. Lanave C, Preparata G, Saccone C, Serio G: A new method for calculating evolutionary substitution rates. J Mol Evol 1984, 20:86-93.

64. Moestrup O, Thomsen HA: Preparation of shadow-cast whole mounts. In Handbook of Phycological Methods. Edited by Gantt E. Cambridge: Cambridge University Press; 1980:385-390.

doi:10.1186/1471-2180-12-271

Cite this article as: Wylezich et al.: Ecologically relevan

choanoflagellates collected from hypoxic water masses of the Baltic Sea have untypical mitochondrial cristae. BMC Microbiology 2012 12:271.

\section{Submit your next manuscript to BioMed Central and take full advantage of:}

- Convenient online submission

- Thorough peer review

- No space constraints or color figure charges

- Immediate publication on acceptance

- Inclusion in PubMed, CAS, Scopus and Google Scholar

- Research which is freely available for redistribution 